\title{
Chemical Constituents and Protection of Biodiversity of Corypha taliera Roxb., a Critically Endangered Plant of Bangladesh
}

\author{
Akhtaruzzaman Chowdhury ${ }^{1}$, Md. Ashraful Alam ${ }^{1}$, Md. Shafiullah Shajib ${ }^{2}$, \\ Mohammad Abdullah Al-Mansur ${ }^{3}$ and Mohammad A. Rashid ${ }^{4}$ \\ ${ }^{1}$ Department of Chemistry, Rajshahi University of Engineering and Technology, Bangladesh \\ ${ }^{2}$ Department of Pharmacy, Stamford University Bangladesh, 51 Siddeswari Road, Dhaka-1217, Bangladesh \\ ${ }^{3}$ Institute of National Analytical Research and Sciences (INARS), BCSIR, Dhaka-1205, Bangladesh \\ ${ }^{4}$ Department of Pharmaceutical Chemistry, University of Dhaka, Dhaka-1000, Bangladesh
}

Received: July 01, 2017; Accepted: July 19, 2017; Published (Web): July 31, 2017

\begin{abstract}
This article focuses on the chemical constituents and protection of biodiversity through plantation of saplings of Corypha taliera Roxb., a critically endangered plant of Bangladesh. Until 2010, the tree in the campus of University of Dhaka, used to be considered as the lone surviving species in the world in nature. Succesive chromatographic separation and purification of the methanol extract of air dried flowers of $C$. taliera provided $\beta$-sitosterol (1), $\beta$-amyrin (2), and betulinic acid (3) for the first time from its flowers. The structures of these purified compounds were established by extensive spectroscopic analysis and comparison of spectral data with published values as well as co-TLC with authentic samples. On the other hand, 500 mature seeds were sown in seed beds in the Medicinal Plant Garden of Faculty of Pharmacy, University of Dhaka, and Azimpur Government Officers' Quarter premises. After 40 days, the root was first seen to grow in its habitat and 85 days later the shoot developed up to $2.5 \mathrm{~cm}$ in height. The rate of germination was found to be $89-93 \%$. The produced saplings were later on planted in different places of Bangladesh for conservation of the plant and protection of biodiversity by ex situ arrangement.
\end{abstract}

Key words: Corypha taliera, biodeversity, chemical constituents, plantation.

\section{Introduction}

Bangladesh is endowed with nearly 5000 floral species where 546 have been identified with significant medicinal values (Yusuf et al. 1994). However, $12.75 \%$ of vascular species (dicotyledons, monocotyledons, pteridophytes, angiosperms, and gymnosperms) of these plants are facing a greater risk of extinction because of threatened biodiversity (Irfanullah, 2011). Plantation is essential for the protection of biodiversity and recuperation of floral species. More desirable biodiversity consequences are anticipated with plantations that make use of indigenous tree species. Plantations ensures habitat for threatened floral species, stipulating the necessity to combine conservation plans of action into control strategies (Bremer and Farley, 2010).
Bangladesh National Herbarium (BNH) has recorded over 100 endangered angiosperm species in Bangladesh (Khan, 1991). C. taliera, a palm tree of Arecaceae family, is one of the endangered angiosperms of Bangladesh. It is locally known as Talipalm. It was first identified by William Roxburgh in 1819 and found to be endemic in Bengal. It is also reported as an endangered species in the whole world (Shoeb et al., 2015). The last specimen of the plant was standing within the campus of the University of Dhaka, Bangladesh which was found to extinct in 2010 after one time flowering and fruiting (Basu and Chakraverty1994; Khan et al., 2001; Shoeb et al., 2015).

Significant evidence regarding economic value, botanical information including panicle initiation,

Correspondence to: Mohammad A. Rashid: Tel: 9661900-73, Extn. 8137, Fax: 880-2-966722; E-mail: rashidma@du.ac.bd 
flowering and fruiting as well as biochemical composition of flowers and fruits of the plant have been recorded primarily (Shoeb et al., 2015; Khondker et al. 2010). Recently, phytochemical screening revealed that the unripe fruits contain significant bioactive molecules including $\beta$ sitosterol, $\beta$-amyrin, betulinic acid, lupeol (Chowdhury et al., 2013), palmitic, myristic, linoleic, arachidic, stearic, lignoceric acids (Shoeb et al., 2013) and $\beta$-sitosterol-3-O- $\alpha$-L-rhamno-pyranosyl$(1 \rightarrow 4)-\beta$-D-xylopyranosyl-( $1 \rightarrow 4)-\beta$-D-glucopyranosyl-( $1 \rightarrow 4$ )- $\beta$-D-glucopyranoside (Shoeb et al., 2015). Bioactivity assays of the extractives of the plant revealed its promising antioxidant and cytotoxic properties and mild to moderate activity against pathogenic microorganisms (Chowdhury et al., 2010). The chemical potential of betulin, an isolated compound of the plant, has been characterized through computational study (Khan et al., 2017). These outcome sprovided significant insights of the medicinal value of the plant and imposed researchers for its preservation and propagation. Efforts to raise the numbers of $C$. taliera populations require adequate knowledge of the fundamental biology of the species concerning the environmental circumstance for germination and propagation (Baskin and Baskin, 2003). Therefore, the present studies were focused on isolation and characterization of compounds from flowers of $C$. taliera and its propagation through sapling plantation all over Bangladesh to shed light towards its conservation.

\section{Materials and Methods}

Collection and identification of plant materials: After identification of the plant by Prof. Salar Khan within the campus of University of Dhaka in 1950, it was kept under close observation. In 2001, Bangladesh National Herbarium, Mirpur, Dhaka published a feature to their Red Data Book with picture of the tree (Rao, 2004). Then the tree was able to draw wide attention of the people, who waited to see the plant blooming. A voucher specimen including leaf, flower, fruit, and the seed of the plant (accession no: DACB-34180) has been deposited in Bangladesh National Herbarium, Dhaka.

Collection and extraction of flowers: Flowers of the plant were collected during February to March, 2009. The air-dried flowers (250 gm) of C. taliera was extracted with methanol at room temperature for 7 days with occasional shaking and stirring and filtered through a cotton plug followed by Whatman filter paper number 1. Evaporation of solvent using a rotary evaporator yielded $5.5 \mathrm{gm}$ of crude mass. A portion of the concentrated methanol extract was fractioned by the modified Kupchan partitioning method (VanWagenen et al. 1993). Successive chromatographic separation and purification of its $n$-hexane soluble fraction yielded a sterol (1), and two triterpinoids $(2,3)$.

Collection of seeds: In January 2010, when the ripe fruits began to fall down quickly, about 500 hundred fruits were collected from the ground and the pericarps were separated carefully from the seeds. Then, the seeds were collected from ripe fruits by taking off the pericarp.

Germination: The separated seeds (300) were sown in seedbed of the Medicinal Plant Garden, Faculty of Pharmacy, University of Dhaka $\left(23^{\circ} 43^{\prime} 40.3^{\prime \prime} \mathrm{N}\right.$ and $90^{\circ} 23^{\prime} 55.6^{\prime \prime}$ E) and another 200 seeds were sown in a seedbed in Azimpur Government Officers' Quarter premises of

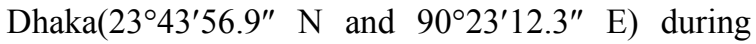
January to February 2010 and water supply was ensured regularly. The number of seed sown, the time taken for germination, total number, and percent of germination were recorded carefully.

Propagation: The germinated seed saplings were allowed to grow for 2-3 months. The mature saplings were subjected to plantation from July-August, 2010 by ex-situ arrangements and plantation in major locations continued until 2016-2017. They were planted in selected places of Bangladesh (Table 1). Growth, irrigation, pathogenic infections of the saplings of the plant have been closely monitored to ensure their survival, propagation, and conservation. 


\section{Results and Discussion}

The present study revealed the isolation and characterization of compounds from methanol extract of flowers of Corypha taliera (tali palm), including germination and propagation in order protect the biodiversity. The tali palm provided three compounds characterized as $\beta$-sitosterol (1) (Jahan et al., 2010), $\beta$-amyrin (2) (Parvin et al., 2009) and betulinic acid (3) (Chandramu et al., 2003) (Figure 1). Although all of these compounds have been isolated form the unripe fruits (Chowdhury et al., 2013), while $\beta$-sitosterol and a steroidal glycoside have been reported from the pericarp (Soheb et al., 2013, 2015), it is important to note that compounds 1-3 are the first report of their occurrence from the flowers of C. taliera. The solitary tree in the
University of Dhaka campus, was endemic to Bengal and in the absence of any other record used to be considered as the only individual of C. taliera species in the wild in its natural state. Obviously, it wasthe last specimen of that plant in the world which warned the scientific community for its plantation and protection of biodiversity. After long waiting near about hundred years, the tree showed a gigantic flower-stalk sprouted from top of the tree in September 2008. The flower of the plant was first seen during late October, 2008. The full blooming of flowers from the flower-stalk was observed in January 2009. It required almost 40 days for first flowering after the initiation of flower-stalk of the plant.

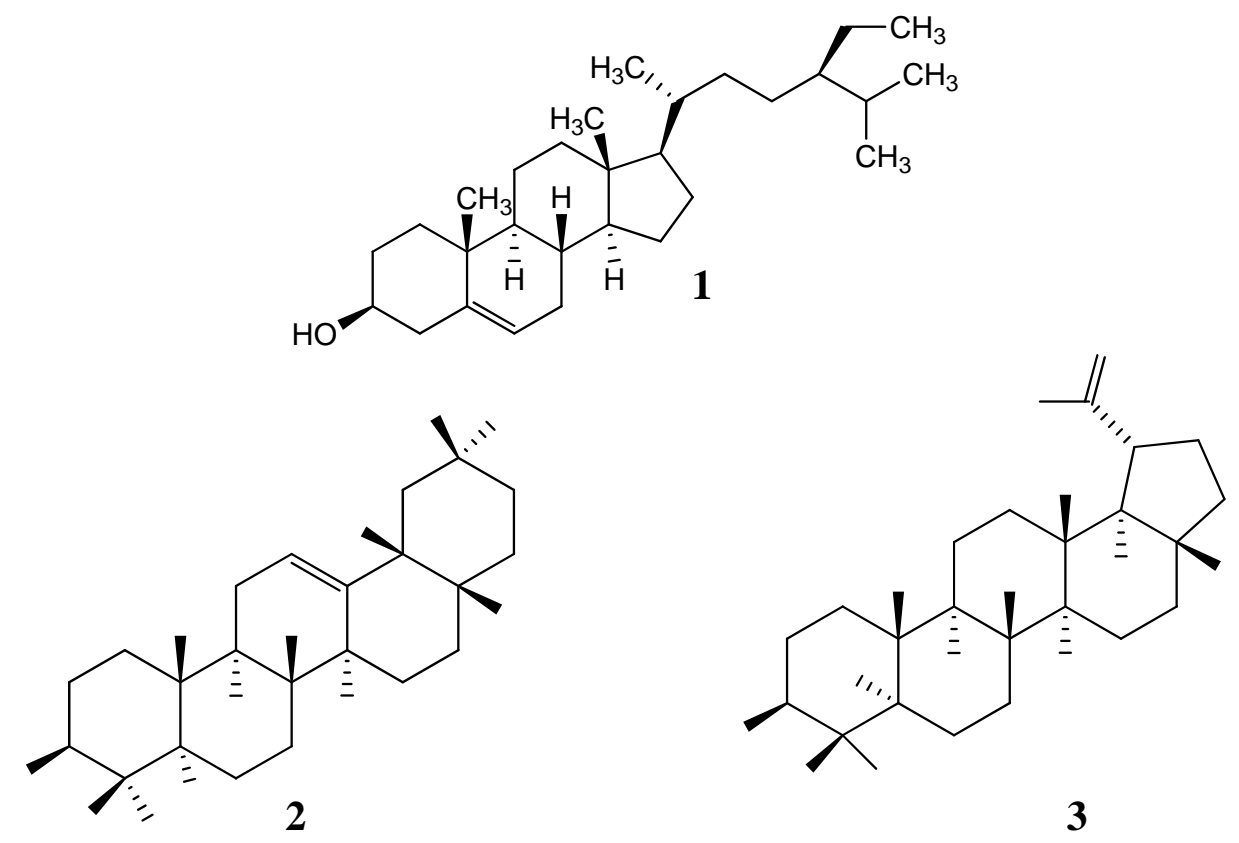

Figure 1. Structure of compounds (1-3) isolated from flowers of C. taliera.

From the first flowering to fully mature and ripe, the fruits took near about 450 days and the ripen fruit finally began to drop down in January 2010. The seeds were collected by removing the pericarp and then sown. After sowing the seeds in February, 2010 it was observed that, a seedling grew with root which was about $3 \mathrm{~cm}$ long (Figure 2A-D and $3 \mathrm{~A}$ ). Out of 300 and 200 seeds sown seeds in the mentioned seed beds, 279 and 178 seedlings were germinated, respectively. The rate of germination was very high (89-93\%). The 2-leaved phase (Figure 3B) of seedlings was observed and growth of seedlings was 
Table 1. Locations of plantation of saplings of $C$. taliera in Bangladesh.

\begin{tabular}{|c|c|c|}
\hline Sl. No. & District & Site of plantation \\
\hline 1. & Dhaka & Medicinal Plant Garden, Faculty of Pharmacy, University of Dhaka \\
\hline 2. & & Asiatic Society of Bangladesh \\
\hline 3. & & Tower Bhaban, Fuller Road, University of Dhaka \\
\hline 4. & & Kabi Nazrul Government College \\
\hline 5. & & Government Shaheed Suhrawardi College \\
\hline 6. & & Dhaka College \\
\hline 7. & & Dhaka Residential Model College \\
\hline 8. & & Government Bangla College, Mirpur \\
\hline 9. & & National Botanical Garden \\
\hline 10. & & Bangladesh Atomic Energy Commission \\
\hline 11. & & Bangla Academy \\
\hline 12. & & Bangladesh Council of Scientific and Industrial Research (BCSIR) \\
\hline 13. & & Baldha Garden \\
\hline 14. & & Dhamrai Government College \\
\hline 15. & & Eden Mohila College \\
\hline 16. & & Jahangirnagar University \\
\hline 17. & & Notre Dame College \\
\hline 18. & & Lalbagh Fort \\
\hline 19. & Manikgang & Government Debendra College \\
\hline 20. & Jhenaidah & Jhenaidah Municipality \\
\hline 21. & & Jhenaidah Cadet College \\
\hline 22. & Jessore & Jessore Cantonment College \\
\hline 23. & Satkhira & Satkhira Government College \\
\hline 24. & Khulna & Government B. L. College \\
\hline 25. & Meherpur & Meherpur Government College \\
\hline 26. & & Meherpur Government Mohila College \\
\hline 27. & & Meherpur Municipality \\
\hline 28. & Moulvibazar & Moulvibazar Government College \\
\hline 29. & & Moulvibazar Government Women's College \\
\hline 30. & Sylhet & Murari Chand (MC) College \\
\hline 31. & Gajipur & Bhawal Badre Alam Government College \\
\hline 32. & & Nuhash Polli \\
\hline 33. & Narsingdi & Narsingdi Government College \\
\hline 34. & Rajshahi & Rajshahi University of Engineering \& Technology (RUET) \\
\hline 35. & & University of Rajshahi \\
\hline 36. & Bogra & Govt Azizul Haque College \\
\hline 37. & Mymensingh & Ananda Mohan College \\
\hline 38. & & Bangladesh Agricultural University \\
\hline 39. & Netrakona & Netrakona Government College \\
\hline 40. & & Netrakona Government College \\
\hline
\end{tabular}




\begin{tabular}{lll}
\hline S1. No. & District & Site of plantation \\
\hline 41. & & BIRISHIRI \\
42. & Sherpur & Sherpur Government College \\
43. & & Sherpur Government Mohila College \\
44. & Comilla & Comilla Victoria Government College \\
45. & & Comilla Government Women's College \\
46. & Brahmanbaria & Brahmanbaria Government College \\
47. & & Brahmanbaria Government Mohila College \\
48. & Barisal & Barisal Cadet College \\
49. & Noakhali & Noakhali Government College \\
50. & Kustia & Kushtia Government College \\
51. & Cox's Bazar & Cox's Bazar Government College \\
\hline
\end{tabular}
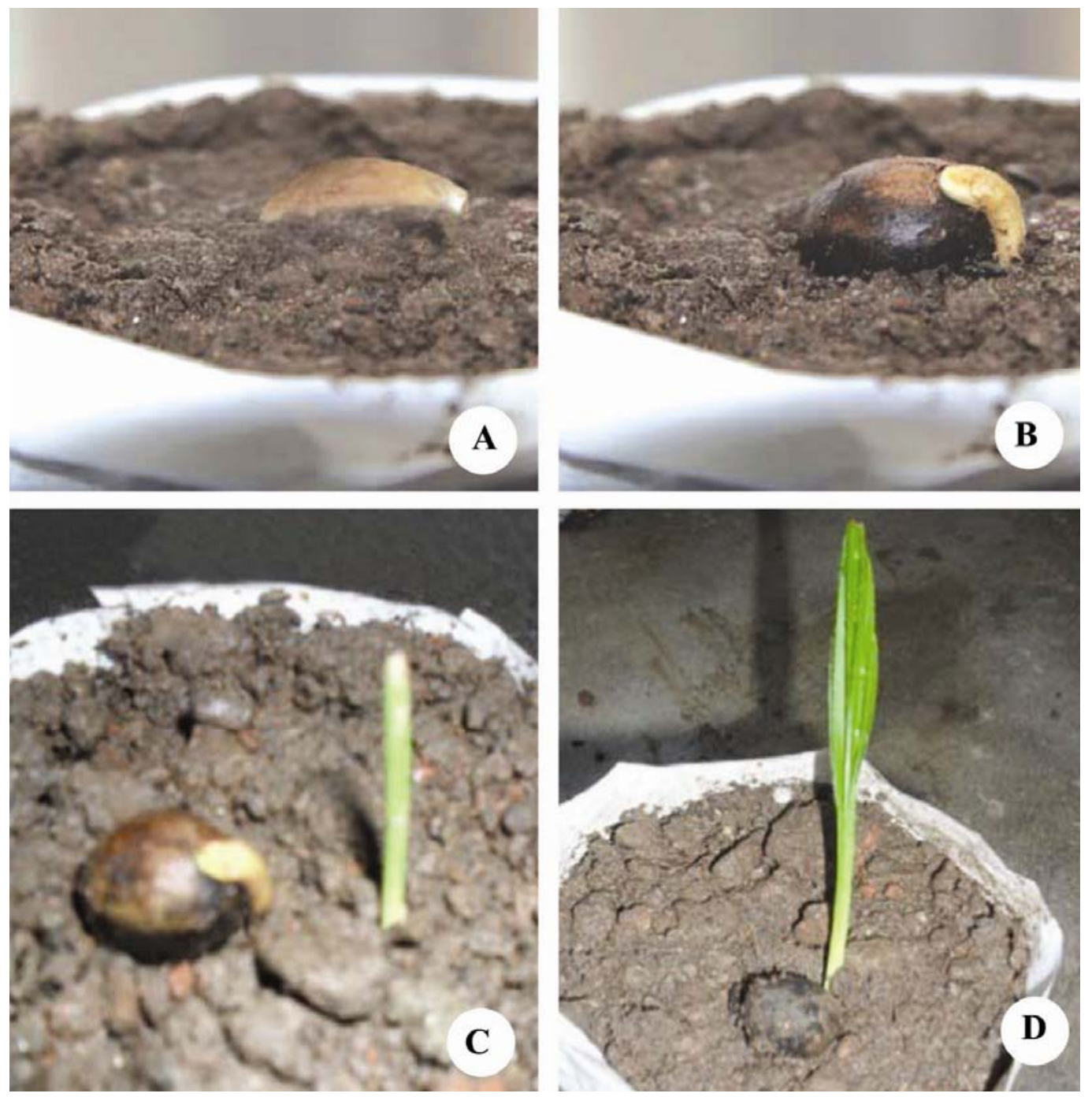

Figure 2. Germination of stages of seed of C. taliera (A) sown seed, (B) germinated seed with shoot, (C) seeds (D) pre-matured sapling. 

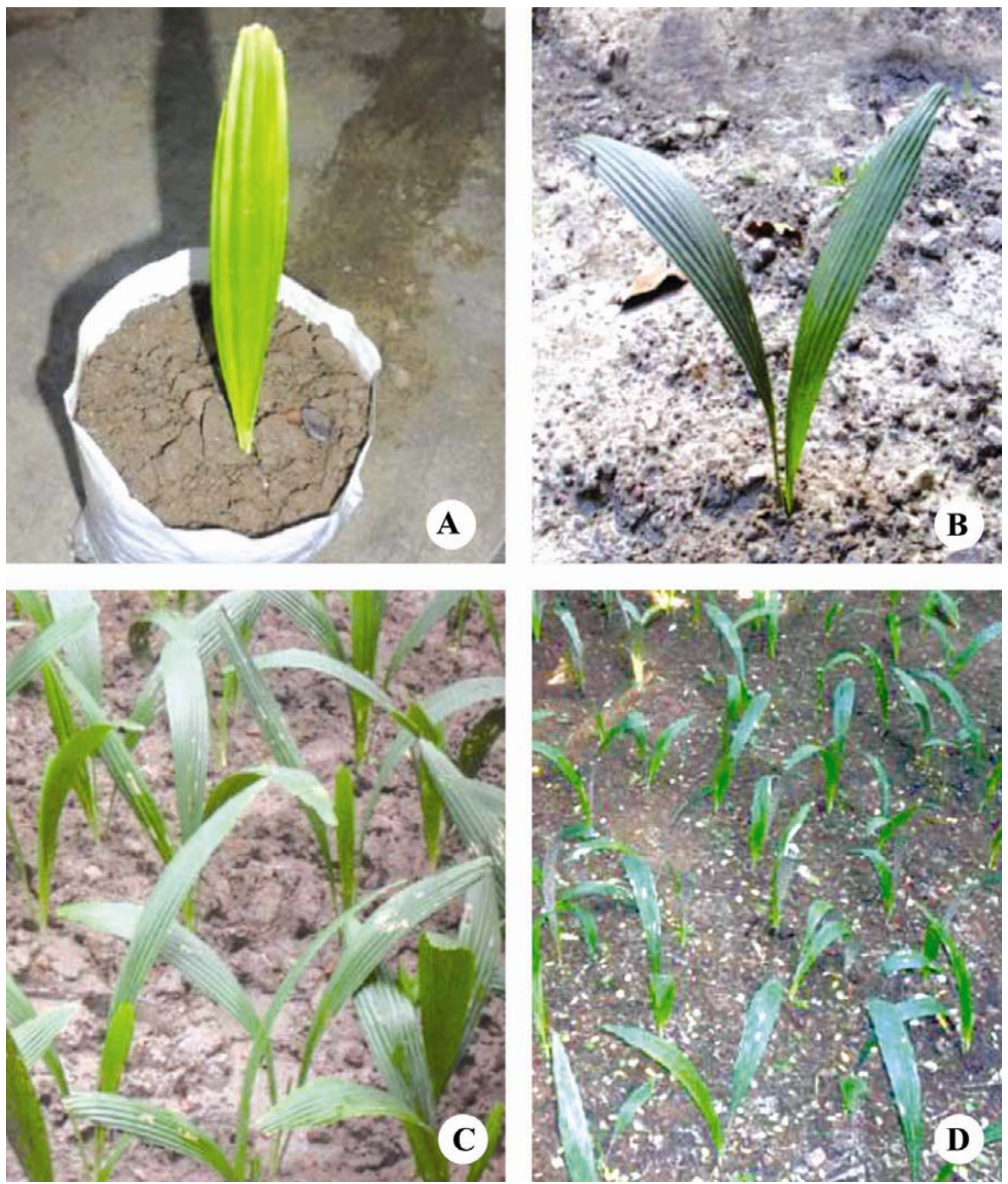

Figure 3. Plantation and maturation of seed saplings of C. talierain seed bed (A) sapling with single leave (B) twig of a sapling after plantation in seed bed (C) matured saplings in a seed bed of Medicinal Plant Garden, Faculty of Pharmacy, University of Dhaka (D) matured saplings in a seed bed of Azimpur Government Officers Quarter premises.

seedlings was determined as $15 \mathrm{~cm}$ after 37 days. When the saplings of C. taliera were about 2-3 months old (Figures $3 \mathrm{C}$ and $\mathrm{D}$ ), proper attempts were taken to plant them in different places of Bangladesh
(Table 1, figure 4A-D) for the conservation of the plant by ex situ arrangement. So far we have been able to complete plantation in more than 100 locations. 

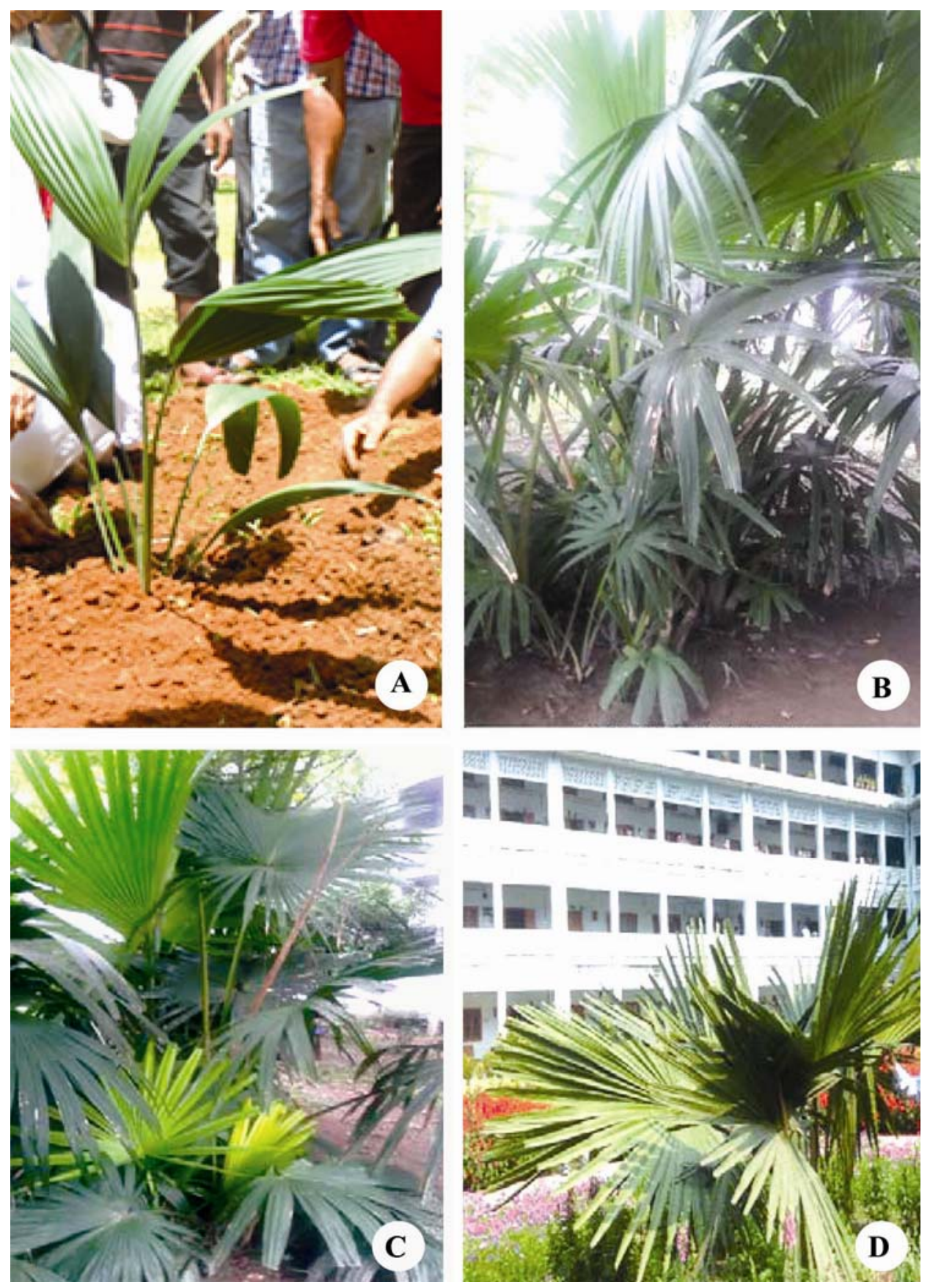

Figure 4. Plantation of C. taliera in selected sites. A. Corypha taliera in BIRISHIRI, Netrokona. B and C. Corypha taliera in Medicinal Plant Garden of Faculty of Pharmacy, University of Dhaka. D. Corypha taliera in front of $2^{\text {nd }}$ Science Building, Rajshahi University, Rajshahi.

It is clearly evident that $C$. taliera, which was thought to be extinct, now exists in reasonably growing stage in many locations of Bangladesh. It is also established that careful and timely efforts by the scientists have made conservation of $C$. taliera successful and there is no wove risk of loss of biodiversity due to its extinction. 


\section{Acknowledgement}

MAR is graceful to the Ministry of Education, Government of the People's Republic of Bangladesh for a research grant (No. 37.01.0000.078.02.018.13$125 / 10 / 2 / 2015)$ to him for the period 2014-15 to 2016-17 to accomplish the work.

\section{References}

Baskin, C.C. and Baskin, J.M., 2003. Seed germination and propagation of Xyris tennesseensis, a federal endangered wetland species. Wetlands, 23, 116-124.

Basu, S.K. and R.K. Chakraverty. 1994. A manual of cultivated palms in India. Botanical Survey of India, Calcutta. pp.38-39

Bremer, L.L. and Farley, K.A. 2010. Does plantation forestry restore biodiversity or create green deserts? A synthesis of the effects of land-use transitions on plant species richness. Biodivers. Conserv.19, 3893-3915.

Chandramu, C., Manohar, R.D., Krupadanam, D.G. and Dashavantha, R.V., 2003. Isolation, characterization and biological activity of betulinic acid and ursolic acid from Vitex negundo L. Phytother. Res. 17, 129134.

Chowdhury, A., Alam, A., Rahman, M.S., Hassan, A. and Rashid, M.A., 2010. Antioxidant, antimicrobial and cytotoxic activities of Corypha taliera Roxb. Lat. Am. J. Pharm.29, 1231-1234

Chowdhury, A., Alam, M.A., Rashid, R.B., Al-Mansur, M.A., Rahman, M.S. and Rashid, M.A., 2013. Steroids and triterpenoids from Corypha taliera Roxb: a critically endangered palm species of Bangladesh. Res. J. Med. Plant.7, 125-129.

Irfanullah, H.M. 2011. Conserving threatened plants of Bangladesh: miles to go before we start? Bangladesh J. Plant Taxon. 18, 81-91.

Jahan, I., Rahman, M.S., Rahman, M.Z., Kaisar, M.A., Islam, M.S., Wahab, M.A. and Rashid, M.A. 2010. Chemical and biological investigations of Delonix regia (Bojer ex Hook.) Raf. Acta. Pharm. 60, $207-$ 215.
Khan M.S. 1991. Towards sustainable development: conservation of genetic resources of Bangladesh. Ministry of Environment and Forest and National Conservation Strategy of Bangladesh Agricultural Research Council, Dhaka.

Khan, M.F., Rashid, R.B., Hossain, M.A. and Rashid, M.A., 2017. Computational study of solvation free energy, dipole moment, polarizability, hyperpolarizability and molecular properties of Betulin, a constituent of Corypha taliera (Roxb.). Dhaka Univ. J. Pharm. Sci. 16, 1-9.

Khan, M.S., Rahman, M.M. and Ali, M.A. 2001. Red Data Book of Vascular Plants of Bangladesh. Bangladesh National Herbarium, Dhaka, p.128

Khondker, M., Hassan, M.A., Alfasane, M.A. and Shahjadee, U.F., 2010. Flowering and fruiting characteristics and biochemical composition of an endangered palm species (Corypha taliera Roxb.). Bangladesh J. Plant Taxon. 17, 79-86.

Parvin, M.N., Rahman, M.S., Islam, M.S., and Rashid, M.A. 2009. Chemical and biological investigations of Dillenia indica. Bangladesh J.Pharmacol.4, 122-125.

Rao, P.C.K. 2004. Flora a gardener's encyclopedia, (Vol. 1). Gordon Cheers for Om Book Service, New Delhi. p. 424

Shoeb, M., Khondker, M. and Nahar, N. 2015. A new steroidal glycoside from Corypha taliera Roxb. a globally endangered species. Nat. Prod. Res., 30, 281285.

Shoeb, M., Nusrat, S.E. and Khondker, M. 2013. Chemical investigation of Corypha talieraRoxb. Bangladesh $J$. Bot.42, 51-54.

VanWagenen, B.C., Larsen, R., Cardellina, J.H., Randazzo, D., Lidert, Z.C. and Swithenbank, C., 1993. Ulosantoin, a potent insecticide from the sponge Ulosa ruetzleri. J. Org. Chem. 58, 335-337.

Yusuf, M., Chowdhury, J.U., Wahab, M.A. and Begum, J. 1994. Medicinal Plants of Bangladesh. Bangladesh Council of Scientific and Industrial Research, Dhaka. 